\title{
Analysis Determinants of Consumer Purchase Interest to Imported Fashion Products on The Instagram Platform
}

Firda Sasmitha Dewi ${ }^{1 *}$,

Norman Arif ${ }^{2}$,

Ali Taman',

Imron Hamzah ${ }^{4}$

1,2,3,4 Department of Sharia Economic, Sekolah Tinggi Ilmu Syariah SBI, Surabaya, Indonesia

\begin{tabular}{ll}
\hline ARTICLE INFO & ABSTRACT \\
\hline ISSN: 2723-1097 & $\begin{array}{l}\text { In this era of social media, it takes more effort to win consumer interest in order to } \\
\text { buy a product being sold, purchasing decisions are the goal of achieving sales. } \\
\text { Therefore, we need a strategy so that companies get consumer appeal so that } \\
\text { Keywords: }\end{array}$ \\
$\begin{array}{l}\text { consumers make buying decisions. The purpose of this study is to analyze the } \\
\text { factors that influence the buying decision of imported clothes on social media, } \\
\text { especially on Instagram. This study uses primary data through a questionnaire. }\end{array}$ \\
$\begin{array}{l}\text { Interest, Imported } \\
\text { Fashion, Social Media }\end{array}$ \\
$\begin{array}{l}\text { The sampling technique used non probability sampling with accidental sampling } \\
\text { method. The samples obtained were 50 samples. This study uses multiple regression } \\
\text { analysis methods using SPSS statistical tools. The empirical results show that } \\
\text { partially the product variables and price variables do not affect the buying decision } \\
\text { on imported clothing, then the promotion variable has a significant effect on } \\
\text { consumer attractiveness to imported clothing. In addition, simultaneously all the } \\
\text { independent variables together have a significant positive effect on the decision to } \\
\text { buy imported clothes on Instagram. }\end{array}$
\end{tabular}

\section{Introduction}

Technological developments have a real impact on all aspects of people's lives. The development of internet technology has given birth to a generation that has different behavior compared to the previous generation. The shift in public interest in the internet is inseparable from the attractiveness of social networking sites that are increasingly mushrooming in cyberspace. Digital platforms such as Instagram, Facebook, Tiktok, and so on are very important for companies, one of which is because they are a medium for promoting their products (Ashley \& Tuten, 2015). Selling products through Instagram media appear at prices that are quite competitive with conventional stores and other social media stores (Miranda, 2017).

One of the digital platforms, namely Instagram, announces that Instagram users continue to experience an increase. Based on Figure 1 from NapoleonCat.com, there are more than 83 million Instagram users in Indonesia, with a ratio of $52.1 \%$ women

Journal of Business and Management Review Vol. 2 No. 32021 Page 192-202

DOI: $10.47153 /$ jbmr23.942021

*Corresponding Author

Email address: virda.mitha@gmail.com 
and $47.9 \%$ men. This data is an extraordinary amount, because it is a big market that is an opportunity for producers. This can be seen from the following percentages:

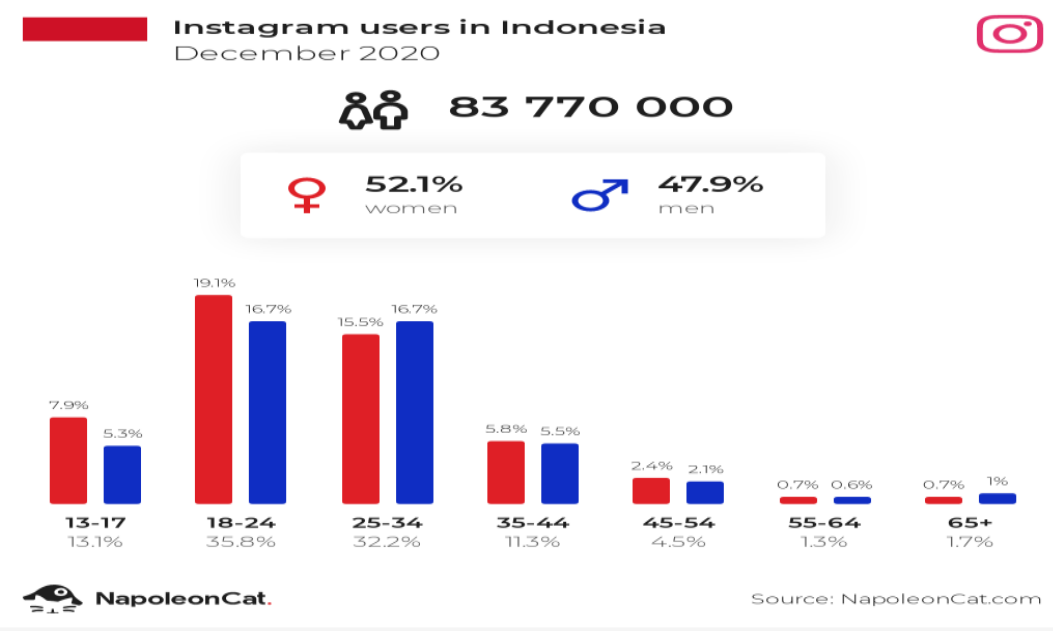

Figure 1. Percentage of Instagram users in Indonesia

Along with the diversity of human needs, companies as producers of goods and services are required to match consumer wants and needs, if the company wants to continue. In addition, with the diversity of human needs, the development of the business world is increasingly rapid, which causes companies to face intense competition (Pitoy et al., 2016). Moreover, the fashion industry has increasingly fierce competition because the fashion industry is rapidly changing and growing, also supported by social media (Kuswoyo et al., 2018). Based on data from the Badan Pusat Statistik (BPS) in the first quarter of 2019 , clothing production grew by $29.19 \%$ on an annual basis, the demand for clothing products continues to increase. This can also be seen from the circulation of clothing sales in online shops. Therefore, with this phenomenon, producers must increase their creativity and innovate with various kinds of new products in order to remain sustainable in the market and get greater opportunities in the market (Reguia, 2014).

Consumers buy a product by considering various things. The emergence of the decision to buy goods indirectly is instant, before the consumer will look for information related to the product to be purchased and compare it with other products (Iskuntianti et al., 2020). On the other hand, for producers to win consumer attractiveness so that consumers are interested in buying is the goal of achieving sales. Therefore it is necessary to have a strategy for the company. This strategy can be applied to the traditional marketing mix concept which consists of the 4Ps, namely product, price, promotion, and place (Ernawati, 2021). A product is anything that a producer can offer to the market as a fulfillment of market needs or desires (Nugroho \& Japarianto, 2013). Therefore, producers must be more observant in determining what products are needed and accepted by the market. One of the products that all humans need is clothing. In addition, the function of clothing has shifted into a demand to fulfill a lifestyle (Hapsari \& Iqbal, 2018). Moreover, women dress not only 
to cover parts of the body, but besides that there are the latest fashion trends that accompany it. Having a charming appearance with fashionable clothes is a characteristic of a woman. In addition, women also have characteristics that are inherent with the slogan of being fond of shopping, especially in the digital era everything is easy as well as shopping. Therefore, it is not surprising that women's fashion products have a very potential market.

Various kinds of clothing models are circulating in order to get consumer buying appeal, as well as imported clothes which are currently busy and are still the prima donna for the current generation. The growing trend of imported clothing is very loved by consumers, especially now that many traders sell used imported clothing with quality that is still suitable for use and relatively cheap prices (Arifah, 2015). Imported clothes are in great demand by consumers because they have many contemporary models that follow the trends of the millennial generation. However, this has a negative impact because the sales of local clothing only follow the trend of foreign products, and make Indonesians more interested and choose foreign products, especially if the imported clothes are used. In Indonesia, imported used clothes are considered as illegal goods because imported used clothes are categorized as dangerous goods that circulate freely without prior checking (Dewi et al., 2020). Based on research from Mubarak \& Sanawiri (2018) that Fashion Lifestyle is proven to have a significant effect on purchase intention, by taking samples from consumers @tangankedua. Based on the results of research from Setiawan (2014) that the correspondent chooses to buy imported clothing products because he feels that imported clothing is of higher quality and prestigious, even though the price of local products is more affordable.

Therefore, based on the above problems, the authors take several factors for further research related to imported clothing products. The factors are marketing stimuli using 3P, namely product, price and promotion. Marketing stimuli will be attached to each product that becomes consumer attractiveness. Therefore this study aims to analyze the determinants of consumer buying decisions on imported clothes on the Instagram platform.

\section{Literature Review}

\section{Marketing concept and orientation}

American Marketing Assosiation (AMA) defines marketing as a management function and several systems in process for creating, communicating, and providing value to customers and for managing customer relationships in a way that benefits all interested parties. The marketing concept focuses on understanding the needs of consumers to create a product or service before they plan for the future, then the marketing concept can be seen as a guide to ensure consumer satisfaction and desires (Kehinde et al., 2016). The purpose of the marketing concept is to provide satisfaction with the wants and needs of consumers or customer oriented (Huda et al., 2017).

Marketing activities are very important because marketing activities are one of the elements that must be considered in order to reach the goals of a company that 
tries to put marketing as the center of company activities. Since the digital era, marketing media has developed rapidly and has begun to switch to social media-based marketing such as Instagram, Facebook, Tiktok, and so on. Today's social media makes it easier for traders to market their products to get consumers' attention. Social media is used as an effective marketing tool to reach consumers, it's just that merchants need to build trust (Anjum et al., 2019). In addition, traders must be more creative in marketing their products so that these products have a special appeal and make consumers curious about the products being sold.

Social Media Marketing

The development of the internet followed by the rapid development in telecommunications, especially smartphones, had a significant impact on consumer behavior. In addition, the increase in internet users is in line with the increase in social media users, so that this is an opportunity for producers to support marketing programs. Social media is a tool to support communication between sellers and buyers in marketing their products quickly and profitably compared to selling directly to the market (Miranda, 2017). One of the marketing strategies is to be able to take advantage of all parts of marketing optimally (Asse, 2018). One of them is by using social media, because many people use social media to create, access and disseminate information (Appel et al., 2020), Likewise with information related to a product, social media is an effective business promotion tool because the promotion network can be wider so that it is useful in business development, increasing product sales, communicating with consumers, and developing a wider market network (Rahmania et al., 2018).

Besides that, there are not a few people who sell on social media so there is a need for innovation for sellers to get consumer appeal through social media. After all, selling on social media requires trust because consumers cannot see directly through pictures (Wibowo, 2015). According to the principles of sharia, marketing activities must be based on seeking the pleasure of Allah Ta'ala, doing the best possible for the common welfare, not for the benefit of groups or individuals. As according to the AlQur'an Surah Al-An'am verse 143 reads:

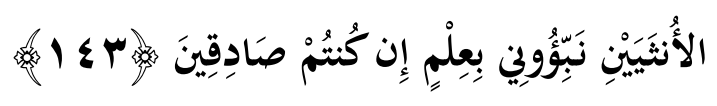

"Tell me with knowledge, if what you say is true"

Based on the paragraph above, selling a product or marketing a product must be in accordance with the existing product conditions. As a seller, he must be able to explain the benefits of a product according to data and facts.

\section{Purchase Decision}

Deciding to buy a product is the last resort for consumers in purchasing the product. Kotler dan Armstrong in Albari \& Safitri (2018) states that the purchase decision is the stage the buyer decides to actually buy the product being considered. Consumer judgment is based on several determinants such as product factors, price, usage, and so on (Andriani \& Handayani, 2020). Some of these determinants are 
included in the marketing stimulus group. According to Kotler \& Keller (2007) that marketing stimuli consist of four groups of variables or commonly known as $4 \mathrm{P}$, including: (1) Product, according to Tjiptono (1999) a product is everything that a manufacturer can offer to look for. , purchased, requested, used, noticed or consumed by the market as a means of fulfilling market needs and wants. (2) Price, according to Swastha, (1990) price is the amount of money needed to add a number of combinations of goods and services.

Factor (3) Promotion, According Kotler (2000) promotion is a part and process of marketing strategy as a way to communicate with the market using a promotional mix. (4) Place (Distribution), distribution becomes part of a series of marketing, which considers how the product reaches the consumer (Huda et al., 2017). Based on the results of research from Andriani \& Handayani (2020) it shows that the decision to use imported used clothing in Surabaya is influenced by lifestyle, product quality, and price. Based on Satria (2017) the variables of price, promotion, and product quality have a simultaneous and partial effect. According Yoebrilianti (2018) promotion has a positive effect on consumer buying interest through social networks. Based on the results of research from Nugroho \& Irena (2017) product, price, place, promotion, cultural influence, social influence, personal influence, and psychological influence simultaneously have a significant effect on consumer purchase intentions on the "W" brand.

\section{Method}

This study uses a quantitative approach using multiple linear regression methods using a statistical tool in the form of SPSS. This study aims to analyze the factors that influence consumer buying decisions on imported clothing. The dependent variable is the decision to buy, then the independent variable is product, price and promotion. The data used in this study is primary data, which is research data that is directly taken on the subject as a source of information under study. Furthermore, the data were obtained through a questionnaire or questionnaire. The location and time of the study were March to April and took place on the Instagram social network.

The sampling technique uses non-probability sampling techniques, namely sampling techniques that do not provide equal opportunities for every element or member of the population to be sampled. The determination of the number of respondents (samples) using the accidental sampling method, namely the sampling method based on chance, so that the sample selected in this study had respondents who happened to comment on the imported clothes seller's Instagram account. The characteristics are women aged 17-45 years and their comments show that the respondent is interested in imported clothes sold on Instagram accounts. The number of samples obtained in this study were 50 samples. Furthermore, data analysis is used to quantify research data into numbers using a Likert scale, with alternative choices of 1 to 5 answers to questions, with a weighted score; $5=$ Strongly Agree; $4=$ Agree; $3=$ Neutral; 2 = Disagree; 1 = Strongly Disagree.

\section{Result and Discussion}




\section{The coefficient of determination}

The coefficient of determination (R2) is used as a way to determine how much influence the independent variables have on the influence of the dependent variable. The results of testing the coefficient of determination that have been carried out on existing data are as follows:

Table 6. Determination Analysis Results

Model Summary ${ }^{b}$

\begin{tabular}{ccccc}
\hline Model & R & R Square & $\begin{array}{c}\text { Adjusted R } \\
\text { Square }\end{array}$ & $\begin{array}{c}\text { Std. Error of the } \\
\text { Estimate }\end{array}$ \\
\hline 1 &, $441^{\mathrm{a}}$ &, 195 &, 142 & 1,765 \\
\hline
\end{tabular}

a. Predictors: (Constant), Promtotion, Product, Price

b. Dependent Variable: Purchase Decision

Source : SPSS, processed data (2020)

According to the Model Summary table above, it shows that the Adjusted $\mathrm{R}$ Square value is 0.195 . This explains that all independent variables, namely product, price, and promotion have a joint contribution of $19.5 \%$ to the dependent variable $(\mathrm{Y})$, namely the purchase decision. While the remaining $80.5 \%$ is explained by other factors outside of this study.

Simultaneous Test (Test F)

The F test is a simultaneous test to determine whether the Product, Price and Promotion variables simultaneously have a significant influence on buying decisions. $\mathrm{F}$ test is done by comparing Fcount and Ftable. From the results of the analysis, the output results are obtained in the following table:

Table 7. Simultaneous Test Results (Test F)

\begin{tabular}{llrrrrr}
\hline \multicolumn{7}{c}{ ANOVA $^{\mathbf{a}}$} \\
Model & Sum of Squares & Df & Mean Square & F & Sig. \\
\hline 1 & Regression & 34,700 & 3 & 11,567 & 3,712 &, $018^{\mathrm{b}}$ \\
& Residual & 143,320 & 46 & 3,116 & & \\
& Total & 178,020 & 49 & & & \\
\hline
\end{tabular}

a. Dependent Variable: Purchase Decision

b. Predictors: (Constant), Promotion, Product, Price

Source : SPSS, processed data (2020)

Based on table 7. The $\mathrm{F}$ test obtained from the results of processing and computerization using the SPSS version 24 program obtained Sig F> 0.018 (5\%) with Fcount 3.712 (Fcount $>$ Ftable) $=3.712>2.790$. It can be concluded that the independent variables simultaneously affect the dependent variable, namely the buying decision. Thus, the first hypothesis is accepted (H1).

This means that overall the variables both product, price, and promotion variables have an influence on the buying decision to provide imported clothes on Instagram. The three variables are a mix of marketing strategies, so when a company already has a product, price, and promotion that becomes a consumer's buying 
decision, the goal of selling is achieved. As according to Ernawati (2021) marketing strategy is applied to the concept of the traditional marketing mix which consists of the 4Ps, namely product, price, promotion, and place.

\section{Hypothesis Testing ( $T$ Test)}

The $\mathrm{T}$ test is used to test the significance or significance of the partial regression coefficients. Testing through the $t$ test, namely by comparing $t$ count with $t$ table at the real level $\mathrm{a}=0.05$. The $\mathrm{t}$ test has a significant effect if the result of the calculation of $\mathrm{T}$ count is greater than T table (Tcount $>$ Ttable) or the probability of error is smaller than $5 \%$ (sig <0.05). In this study, the table used was 1.675 .

Table 8. Partial Test Results (T Test)

\begin{tabular}{|c|c|c|c|c|c|c|}
\hline \multicolumn{7}{|c|}{ Coefficients ${ }^{a}$} \\
\hline & \multirow{2}{*}{ Model } & \multicolumn{2}{|c|}{$\begin{array}{l}\text { Unstandardized } \\
\text { Coefficients }\end{array}$} & \multirow{2}{*}{$\begin{array}{l}\text { Standardized } \\
\text { Coefficients } \\
\text { Beta }\end{array}$} & \multirow{2}{*}{$\mathbf{t}$} & \multirow{2}{*}{ Sig. } \\
\hline & & B & Std. Error & & & \\
\hline \multirow[t]{4}{*}{1} & (Constant) & 6,283 & 2,075 & & 3,027 & ,004 \\
\hline & Product & 192 & ,150 & 188 & 1,283 & 206 \\
\hline & Price & -,165 & 152 &,- 159 & $-1,082$ & 285 \\
\hline & Promotion & 370 & 142 & ,384 & 2,604 & ,012 \\
\hline
\end{tabular}

Dependent Variable: Purchase Decision

Source : SPSS, processed data (2020)

Based on the table above obtained from the results of processing and computerization using the SPSS version 24 program, the $t$ test for each variable $X$ is as follows:

\section{a) Effect of Product on Purchasing Decisions}

The product variable (X1) shows that the value of $\mathrm{T}$ count is greater than $\mathrm{T}$ table $(1.283<1.675)$ or sig < a $(0.206<0.05)$, which means that the product variable $(X 1)$ does not have a partial effect on buying decisions on imported clothing on Instagram. Based on these results, it means that it is concluded that the product has no influence on consumer buying decisions on imort clothes on Instagram.

In order to win the competition and get customer satisfaction with the product, one of the factors is the product it consumes (Usman et al., 2020). Products purchased by consumers must have good quality because of the quality of the product, consumers will feel satisfied with the product and will even make a continuous purchase. Instagram media is a virtual media so when buying products on Instagram media consumers only see pictures and product descriptions, they cannot see the product directly. Research from Setiawan (2014) views the majority of respondents that the quality of local fashion products is below the quality of imported fashion products. But in reality, not all imported products are of good quality, especially when there are used imported clothes (Arifah, 2015). Therefore, the product does not affect the 
decision to buy imported clothing because consumers are not satisfied with products that have been purchased before, or are based on reviews from other consumers regarding these products.

\section{b) Effect of Price on Purchasing Decisions}

The product variable $(\mathrm{X} 2)$ shows that the $\mathrm{T}$-count value is greater than $\mathrm{T}$-table $(-1.082<1.675)$ or sig < $(0.285<0.05)$, which means that the product variable $(X 2)$ does not have a partial effect on the decision to buy imported clothes on Instagram. Based on these results, it means that it is concluded that the price of imported clothing has no influence on consumer buying decisions in buying imported clothes on Instagram.

Price is one of the main things that are considered in purchasing decisions for consumers. Because the price determines the value that must be paid to get a product (Devi, 2019). Based on research from Setiawan (2014) that the price of imported clothing is higher than the price of local clothing. The high price of imported clothing in the market is because consumers expect that the quality of the product is in line with the price. Therefore, imported clothes tend to be more expensive because of the expectation that imported clothes will be of good quality. But in reality, not all of them are of good quality and there are also many imported clothes that have relatively cheap prices, one of which is used imported clothing. Therefore there is disappointment from consumers when buying imported clothes on Instagram that are not in accordance with consumer expectations.

c) Effect of Promotion on Purchasing Decisions

The product variable $(\mathrm{X} 3)$ shows that the $\mathrm{T}$-count value is greater than $\mathrm{T}$-table $(2.604>1.675)$ or sig $<a(0.012<0.05)$, which means that the product variable $(X 3)$ has a partial effect on the decision to buy imported clothes on Instagram. Based on these results, it can be concluded that promotion has a partial influence on consumer buying decisions on imported clothes on Instagram.

Promotion is a way for sellers to offer their goods to consumers, especially in this social media era. Promotion is one component of the marketing mix, the role of promotion can influence consumer buying interest (Hakim et al., 2019), so that promotion is a determinant of consumer attractiveness to buy. The more attractive the seller is to promote an item, the seller will have a greater chance of getting purchases from consumers.

d) Based on the results of the regression coefficient, it can be concluded that the influence of the promotion variable is greater because Tcount> Ttable $(2.604>1.675)$ than the other variables, namely the product Tcount $<$ Ttable $(1.283<1.675)$ and the price of Tcount $<$ Ttable $(-1.082<1.675)$. The results of the regression coefficient can be seen that the influence of the promotion variable is greater than the other variables, namely product and price.

\section{Conclusion}


This study aims to analyze the factors that influence consumer buying decisions on imported clothes on social media, especially on the Instagram platform. Based on the results of the study, it is concluded that Instagram is an application that can be relied on to market imported products in order to attract consumer buying interest. From the research results, the most influential factor partially is promotion, while product and price partially do not have a significant effect on consumer buying decisions on imported clothes on Instagram. This is because Instagram is the most appropriate place to promote a product.

Based on these results, there are suggestions as input and consideration to be able to increase attractiveness and get consumer buying interest, namely (1) Sellers are required to maintain the quality of their promotions which are already good and improve product quality and slightly reduce prices to be more economical. so that it can increase purchases from consumers that are greater than before. (2) For further researchers, they should expand the research so that they get more complete information about the factors that influence consumer buying decisions on imported clothes on Instagram.

\section{References}

Albari, \& Safitri, I. (2018). The influence of product price on consumers' purchasing decisions. Review of Integrative Business and Economics Research, $7(2), 328-337$.

Andriani, A. D., \& Handayani, C. M. S. (2020). Decision in Purchasing used Import Clothes in Surabaya. International Journal of Economics, Business and Accounting Research (IJEBAR), 4(4), 1089-1098.

Anjum, S., Chai, J., Frimpong, A. N. K., \& Akram, U. (2019). The Impact of Social Media Characteristics on E-Commerce Use Behavior Among Youth in Developing Countries. International Journal Information Systems and Change Management, 11(2),

118-207.

https://doi.org/10.1504/IJISCM.2019.10026376

Appel, G., Grewal, L., Hadi, R., \& Stephen, A. T. (2020). The Future of Social Media in Marketing. Journal of the Academy of Marketing Science, 48, 79-95.

Arifah, R. N. (2015). Kendala-Kendala Pencegahan Perdagangan Pakaian Bekas Impor di Kota Malang. De Jure, Jurnal Syariah Dan Hukum, 7(1), 89-100.

Ashley, C., \& Tuten, T. (2015). Creative Strategies in Social Media Marketing: An Exploratory Study of Branded Social Content and Consumer Engagement. Psychology $\mathcal{E} \quad$ Marketing, 32(1), 15-27. https://doi.org/10.1002/mar

Asse, R. A. A. (2018). Strategi Pemasaran Online (Studi Kasus Facebook Marketing Warunk Bakso Mas Cingkrank di Makassar). Jurnal Komunikasi KAREBA, 7(2), 219-231.

Devi, L. K. I. (2019). Pengaruh kualitas produk, harga dan promosi terhadap 
keputusan pembelian pada marketplace Shopee. In Skripsi UIN Sunan Ampel. UIN Sunan Ampel Surabaya.

Dewi, N. M. I. K., Widiati, I. A. P., \& Sutama, I. N. (2020). Implikasi Penjualan Pakaian Bekas Impor bagi Konsumen di Kota Denpasar. Jurnal Interpretasi Hukum, 1(1), 216-221.

Ernawati, S. (2021). The Influence Of Expanded Marketing on Visiting Interest to Lawata Beach in Bima , Indonesia. Journal of Business Management Review, 2(1), 12-22. https://doi.org/10.47153/jbmr21.882021

Hakim, M., Lukitaningsih, A., \& Susanto. (2019). Pengaruh Promosi, Harga, Kualitas Produk Terhadap Minat Beli Sepeda Motor Honda Di Kota Yogyakarta. Jurnal Ekobis Dewantara, 2(3), 1-6.

Hapsari, A. D., \& Iqbal, M. (2018). Analisis Segmentasi Pasar Fashion Wanita berdasarkan Motif Pembelian dan Shopping Lifestyle (Survei pada Konsumen Fashion Item Wanita di Kota Surabaya dan Malang). Jurnal Administrasi Bisnis (JAB), 64(2), 27-35.

Huda, N., Hudori, K., Fahlevi, R., Badrussa'diyah, Mazaya, D., \& Sugiarti, D. (2017). Aplikasi, Pemasaran Syariah; Teori dan. Kencana.

Iskuntianti, N. D., Faisal, M. A., Naimah, J., \& Sanjaya, V. F. (2020). The Influence Of Brand Image, Lifestyle, And Product Quality on Purchasing Decisions. Journal of Business Management Review, 1(6), 436-448. https://doi.org/10.47153/jbmr16.752020

Kehinde, O. J., Adegbuyi, O., Akinbode, M., \& Taiye, B. (2016). Marketing Concept And The Satisfaction Of Consumer Needs: The Nigerian Consumers ' Experience. Research Journali's Journal of Marketing, 4(1), 1-16.

Kotler, P. (2000). Manajemen Pemasaran Edisi Milenium, Jilid 2. Prenhallindo.

Kotler, P., \& Keller. (2007). Manajemen Pemasaran, Jilid I, Edisi Kedua belas. PT. Indeks.

Kuswoyo, F., Minarsih, M. M., \& Fathoni, A. (2018). Analisis Strategi Bisnis Dengan SWOT pada ANA Fashion. Jurnal of Management, 4(4), 1-17. http://jurnal.unpand.ac.id/index.php/MS/article/viewFile/1119/1092

Miranda, S. (2017). Pengaruh Instagram sebagai Media Online Shopping Fashion terhadap Perilaku Konsumtif Mahasiswi Fakultas Ilmu Sosial dan Ilmi Politik Universitas Riau. JOM FISIP , 4(1), 1-15.

Mubarak, S. A., \& Sanawiri, B. (2018). Pengaruh Fashion Lifestyle terhadap Purchase Intention (Studi Pada Konsumen Pakaian Second Hand @Tangankedua). Jurnal Administrasi Bisnis (JAB), 55(3), 33-40.

Nugroho, A. R., \& Irena, A. (2017). The Impact of Marketing Mix, Consumer's Characteristics, and Psychological Factors to Consumer's Purchase Intention on Brand "W" in Surabaya. IBuss Management, 5(1), 55-69.

Nugroho, R., \& Japarianto, E. (2013). Pengaruh People, Physical Evidence, Product, Promotion, Price, dan Place terhadap Tingkat Kunjungan di Kafe 
Coffe Cozies Surabaya. Jurnal Manajemen Pemasaran Petra, 1(2), 1-9.

Pitoy, C. V., Tumbel, A., \& Tielung, M. (2016). Analisis Strategi Bersaing Dalam Persaingan Usaha Bisnis Document Solution (Studi Kasus Pada Pt. Astragraphia, Tbk Manado). Jurnal Berkala Ilmiah Efisiensi, 16(3), 302-312.

Rahmania, F. D., Soetjipto, B. E., \& Rahayu, W. P. (2018). Online Marketing Using Social Media Performed by Star-Up Entrepreneurs in Kediri Regency. Jurnal Pendidikan: Teori, Penelitian, Dan Pengembangan, 3(5), 641647.

Reguia, C. (2014). Product Innovation and the Competitive Advantage. European Scientific Journal, 1(June), 140-157.

Satria, A. A. (2017). Pengaruh Harga, Promosi, dan Kualitas Produk terhadap Minat Beli Konsumen pada Perusahaan A-36. PERFORMA: Jurnal Manajemen Dan Start-up Bisnis, 2(1), 45-53. https://doi.org/10.34127/jrlab.v6i1.169

Setiawan, E. (2014). Analisis Sikap Konsumen terhadap Produk Fashion Lokal dan Impor. Jurnal Economia, 10(1), 38-47.

Swastha, B. (1990). Manajemen Pemasaran Modern. Liberty.

Tjiptono, F. (1999). Strategi Pemasaran. Andi.

Usman, H., Kanitra, A. K., \& Maharani, A. (2020). Customer Satisfaction, Revisit Intention and Promoting Ferry Transportation. Journal of Business Management Review, 1(3), 186-207. https://doi.org/10.47153/jbmr13.362020

Wibowo, R. A. (2015). Kesuksesan E-commerce ( OnlineShopping ) Melalui Trust dan Customer Loyalty. Jurnal Ekonomi Bisnis, 20(1), 1-52.

Yoebrilianti, A. (2018). Pengaruh Promosi Penjualan Terhadap Minat Beli Produk Fashion dengan Gaya Hidup Sebagai Variable Moderator (Survei Konsumen pada Jejaring Sosial). Jurnal Manajemen, 8(1), 20-41. 